\title{
PRODUCTION EFFICIENCY OF SEAWEED FARMING IN TARAKAN NORTH BORNEO
}

\section{Efisiensi Produksi Rumput Laut di Kota Tarakan Kalimantan Utara}

\author{
Banyuriatiga $^{1}$, Dwidjono Hadi Darwanto ${ }^{2}$, Lestari Rahayu Waluyati ${ }^{2}$ \\ ${ }^{1}$ Student of Postgraduate Program of Faculty of Agriculture, Universitas Gadjah Mada \\ ${ }^{2}$ Lecturers of Faculty of Agriculture, Universitas Gadjah Mada \\ Jl. Flora, Bulaksumur, Kec.Depok, Kabupaten Sleman, \\ Daerah Istimewa Yogyakarta 55281 \\ banyuria3@gmail.com
}

Diterima tanggal 25 April 2017 ; Disetujui tanggal 2 Juni 2017

\begin{abstract}
This study aims to determine: (1) the factors that influence the production of seaweed and (2) the level of technical efficiency obtained by seaweed farmers in Tarakan. Since 2009, most of the fishermen on the coast of Amal turned into seaweed farming as it is more profitable and easier to cultivate. The basic method used in this research is descriptive method while the location of the research was determined by intentional or purposive sampling. The sample selection for seaweed farmer respondents used simple random sampling of 100 seaweed farmers. The results showed that the factors of production which have positive and significant impact on seaweed production in Tarakan are farm area, seeds, labor and dummy for location. The technical efficiency in a secure or unsecured locations are 0,93 and 0,82 , respectively, with the average value of the technical efficiency of seaweed farmers in general is 0,92 . Socio-economic factors affecting technical inefficiency are farmers'age, farming experience, number of family members, education and dummy for location. However, the experience of farming and dummy for location have negative coefficients which means that both are able to increase the level of technical efficiency of seaweed farming.
\end{abstract}

Keywords: inefficiency, seaweed, stochastic frontier, technical efficiency

\section{INTISARI}

Penelitian ini bertujuan untuk: (1) mengetahui faktor yang mempengaruhi produksi rumput laut di Tarakan dan (2) mengetahui tingkat efisiensi teknis yang diperoleh petani rumput laut di Kota Tarakan. Sejak tahun 2009 hampir sebagian besar nelayan di pesisir Pantai Amal beralih menjadi petani rumput laut karena menyadari rumput laut lebih menguntungkan dan mudah untuk dibudidayakan. Metode dasar yang digunakan dalam penelitian ini adalah metode deskriptif dan lokasi penelitian ditentukan secara sengaja atau purposive sampling. Pemilihan sampel untuk responden petani rumput laut dilakukan dengan metode simple random sampling sebanyak 100 petani rumput laut. Hasil penelitian menunjukkan faktor-faktor produksi yang berpengaruh positif dan signifikan terhadap produksi rumput laut di Tarakan adalah luas kavlingan, jumlah benih, tenaga kerja dan dummy lokasi. Nilai rata-rata efisiensi teknis petani responden baik pada lokasi aman maupun tidak aman masing-masing adalah sebesar 0,93 dan 0,82. Rata-rata nilai efisiensi teknis petani rumput laut secara umum adalah 0,92. Faktor sosial ekonomi yang mempengaruhi inefisiensi teknis adalah umur, pengalaman usahatani, jumlah anggota keluarga, pendidikan dan dummy 
lokasi. Namun, hanya pengalaman usahatani dan dummy lokasi yang nilai koefisiennya negatif dan memiliki arti keduanya mampu meningkatkan tingkat efisiensi teknis usaha tani rumput laut.

Kata kunci: efisiensi alokatif, efisiensi ekonomi, efisiensi teknis, rumput laut

\section{INTRODUCTION}

Indonesia as an archipelago with 17.504 islands and has long reach $81.000 \mathrm{~km}$ coastline has huge potential for the development of seaweed, where development activities have been carried out in the marine areas of Indonesia from Nanggroe Aceh Darussalam to Papua. Indicative vast land that can be utilized for the Indonesian seaweed cultivation reached 769.452 ha, but there are only $50 \%$ or 384.733 ha are effectively utilized.

Based on data from FAO, in 2011 Indonesia is the biggest producer in the world for Eucheuma Cottoni and Gracilaria seaweed by providing each share for Eucheuma Cottoni (98,2\%) and Gracilaria (90,5\%) to world seaweed production (Fishstat FAO, 2013).

According to provisional data of the Ministry of Marine and Fisheries, national seaweed production in 2014 reached 10,2 million tons, an increase of more than threefold. Where previously, seaweed production in 2010 only around 3,9 million tons. It proves that the seaweed is unreliable as a source of livelihoods of coastal communities. Apart from the cultivation way that is easy and cheap, the market opportunity of seaweed market is still wide open (Balitbang KKP RI, 2010). Seaweeds are marine plants that has economically important potency and have been trafficked and exploited by humans because they contains pikokolloid and polisakharida which processed into carrageenan and alginates.

Seaweed production has a big contribution to total aquaculture production where national production of seaweed gives a share $60 \%$ of the aquaculture production. The development of seaweed production from 2010 to 2013 showed a very positive trend, with average production growth at an annual rate reached $27,88 \%$ while this figure is also able to exceed the target set per year, with the average achievement is $136,9 \%$. The aspect that underlie the high achievement of this commodity is that seaweed farming has a maintenance period short enough so that the velocity of venture capital can be faster, as well as an easy way of cultivation. Seaweed is also suitable for cultivation in the area with low rainfall which is also one of the characteristics of the poverty area. Another advantage is the use of simple technology relatively and market opportunities that are still open considering the seaweed is the raw material for some industries, 
such as biofuels, gelatin, carrageenan, cosmetics, pharmaceuticals and others. In addition, the government also continuously make breakthrough efforts including the development of seaweed industrialization. Seaweed is a commodity that has a huge economic strategic value both as a driver of economic and the support of the national economy.

Indonesia as a part of the Coral Three Angel (the world's coral triangle) were treated so large resource potential and diverse types of seaweed. The identification results mention that Indonesia has more than 550 types of seaweed potential, only in terms of utilization no more than 5 types of seaweed that has new high potential value to utilize. On the other hand seaweed market share in many countries are also increasingly, such as Hong Kong, South Korea, France, UK, Canada, USA, Japan and other industrialized countries making it as a commodity producer of foreign exchange.

The highest export trends from 2006 to 2009 produced by Central Java and South Sulawesi Provinces, which each amounted are $54,25 \%$ and $44,71 \%$, respectively. Then, the quantity was changed where the greatest value in 2010 increased compared to 2009 which is amounted about $72,99 \%$ in quantity or at about $127,97 \%$ in value for that of the South Sulawesi province. From the available information, the volume of Indonesian exports in 2014 reached
206.452 tons with a value of USD 279,54 million. The data is increased compared to 2013, where export volume reached 181.924 tons with a value USD 209,70 million (Balitbang KKP RI, 2010).

Over the last five years (1999 - 2003) the exports of seaweed has increase, in 1999 amounted 10.542,15 tons with a production volume is 88.200 tons, and in 2003 the exports increased at about $15.338,81$ tons or at growth rate of $51,43 \%$ or at the production amounted 110.000 tons. In 2012, the largest export destination of Indonesian seaweed is China that counted at $67 \%$ or valued as US\$ 90 million, followed by the Philippines, Chile, Hong Kong and South Korea. Meanwhile, export destinations of Indonesian seaweed which has the highest trend in the period 2008 - 2012 was China, (30,72\%), Hong Kong (14,51\%), and Vietnam (13,64\%). In particular, the development of seaweed production in Tarakan has increased from year to year, although in 2016 seaweed production has decreased drastically. This is probably caused by lower selling prices. Some of the factors that caused the price of seaweed lower is the discourse of the imposition of export duties on seaweed and plans to export restrictions, the world economic crisis primarily China as the largest export market, an increase in world production from Indonesia and the Philippines as well as the quality factor or the quality is not standard. 
Most of seaweed sold is dried seaweed and not yet processed into high value products as there has been no seaweed processing industry. The fall in production in 2016 has led to the decrease of sales. Most seaweed from Tarakan traded in a dry form with the destination of the sale is Makassar, Bali, Jakarta and Surabaya.

Extensive coastal area in Tarakan reach $\pm 70 \mathrm{~km}^{2}$, it supports the development of fishery exploitation as the people's livelihood in Tarakan. Fishery potential reach to 10 thousand tons in a year. Just catching threshold is limited to 80 percent of the existing potency to maintain the continuity in the future. One of the potential fishery now used as the livelihoods of coastal communities is the cultivation of seaweed.

Seaweed farming in Tarakan is something new if compared to the cultivation of seaweed in other regions in Indonesia. Since 2009, fishermen in the village of Amal Beach in East Tarakan make seaweed cultivation as an alternative employment for the families along the coast of charity. But the fisherman began to realize that seaweed turned out to be more profitable and easier to be planted, so that the fishermen are turning into seaweed farmers. On average, every family has seaweed area between 200-2100 rope with each length of rope about 15 depa or equivalent to 15 meters. Seaweed production in general has increased in the period of 2012-2015. The highest increase in seaweed production occurred in 2015 which amounted to $18,595,762$ kilograms (Dinas Kelautan dan Perikanan Kota Tarakan, 2016)

However, behind the potential of seaweed farmers still face challenges cliches, the quality and quantity of seaweed production from Tarakan is not well as that from Sebatik Island and Nunukan. Problems of low productivity of seaweed in Tarakan allegedly farmers are not efficient in the use of production inputs. Farmers in pursuit of farming are limited in the use of broad farm area, seeds, labor and the number of fuel used.

Based on the research conducted by Azwir et al (2011) in the Agro Economic journal titled Financial Analysis and Production Efficiency Farming Seaweed in Kendari, found that the factors of production (input) has positive effects on production and productivity seaweed in Kendari is widely farm area, number of seeds, level of education and dummy location. Allocation rate of production input used by farmers' will affect the amount produced, the level of productivity, and can give an idea of the level of efficiency achieved by farmer (Ajao, 2012).

In addition, that was also influenced by the combination of the use of production inputs, the level of farm efficiency influenced by socio-economic characteristics of farmers. This study aims 
to determine the factors that influence the production of seaweed in Tarakan and determine the level of technical efficiency obtained seaweed farmers in Tarakan.

\section{METHODS}

The basic method used in this research is descriptive method, a method which researching the status of a group of people, an object, a set of conditions, a system of thought, or a class of events

in the present. The goal is to create a description, picture or painting in a systematic, factual and accurate information on the facts, properties and relationships between phenomena which investigated.

The research location is determined intentional or purposive sampling decider research areas deliberately chosen taking into consideration certain things, to the purpose of the study. The research was conducted in Tarakan, North Borneo considering that this area is one of the new areas of development of seaweed given its strategic location at once surrounded by ocean. The respondents consisted of 100 farmers who do the cultivation of seaweed in the Amal Coast of East Tarakan which is determined using the slovin methods with the following formula : $n=\frac{N}{N\left(d^{2}\right)+1}$ $n=\frac{N}{N\left(d^{2}\right)+1}$ where $\mathrm{N}$ is total population and $\mathrm{d}$ is fault tolerance limit.

Types and sources of data in this research consisted of 2 types, primary data and secondary data. The primary data obtained directly from seaweed farmers in Tarakan, while secondary data supporting data originating from agencies associated with the research. Methods of data collection consisted of: observation, interviewing, recording techniques and literature.

Before conducting an analysis of the model, in order to get a good model of the previously performed classical assumption. Classic assumption test that is often used for this type of cross section data including normality test, multicollinearity, and heteroscedasticity test.

\section{Analytical Framework}

Analysis of the factors affecting the production of seaweed and technical efficiency was used Cobb Douglas production function and estimated using Ordinary Least Squares (OLS). Production factors are used to determine the impact on seaweed production from this research is extensive farm area (X1), the use of seeds (X2), labor (X3), the amount of fuel usage (X4), age (X5), the experience of farming (X6), the amount of family members (X7), educational level (X8) and dummy location. Dummy location is a variable where there are two categories of locations used are secure and unsecure. Secure according to the criteria set by the local government is not more than 10 kilometers from shore and given number 1 and for unsecure is 0 .

Multiple linear regression equation used is as follows : 
$\operatorname{Ln} Y=\operatorname{Ln} a+\beta 1 \operatorname{Ln} X 1+\beta 2 \operatorname{Ln} X 2+\beta 3$

$\operatorname{Ln} X 3+\beta 4 \operatorname{Ln} X 4+\beta 5 \operatorname{Ln} X 5+$

$\beta 6 \operatorname{Ln} X 6+\beta 7 \operatorname{Ln} X 7+\beta 8 \operatorname{Ln} X 8$

$+\mathrm{d} D+\mathrm{e}$

After multiple linear regression and then do t-test. The t-test is a test that aims fatherly partial test the effect of a particular independent variable on the dependent variables. The t-test is done by comparing the t-sig (significance) at the error rate of each influencing factor. If the t-sig value is smaller than $\alpha$ it can be concluded that the independent variables individually has significant effect on the dependent variable.

As for knowing the level of technical efficiency of data processing is done using Frontier 4.1 applications. To get technical efficient (ET) on seaweed farming can be calculated as follows :

$E T=\frac{Y_{i}}{\hat{\mathrm{Y}}_{i}}=\frac{E\left(Y_{i} \mid U_{i}, X_{i}\right)}{E\left(Y_{t} \mid U_{i}=0, X_{i}\right)}=E\left[\frac{\exp \left(-U_{i}\right)}{\varepsilon_{i}}\right]$

Where ETi is the farmers' technical efficiency to-i, exp (-E[ui| \&i ]) is the expected value (mean) of Ui on condition $\varepsilon i$, so $0 \leq \mathrm{TEi} \leq 1$. The technical efficiency value is inversely related to technical inefficiency effects and is only used for functions that have a certain number of outputs and inputs (cross section data). If the TE value closer to 1 the farm can be said more efficient on techniques and if the TE value closer to 0 , then it can be said farming techniques increasingly inefficient manner.

Technical efficiency value can be determined from the data processing with
Frontier. Justification efficiency value is (Viswanathan et al, 2001) :

1. If the value of technical efficiency is equal to one, then the use of inputs in farming seaweed is efficient.

2. If the value of technical efficiency is not equal to one, then the use of inputs in farming seaweed is not efficient.

To calculate the value of technical inefficiency done through analysis of factors that affect farmers' technical inefficiency. Factors thought to affect the level of technical inefficiency seaweed farmers are farmers age, educational level of farmers, farming experience, the number of family members. Mathematically, technical inefficiency (U) is written as follows :

$\mathrm{Ui}=\delta_{0}+\delta_{1} \mathrm{Z}_{1}+\delta_{2} \mathrm{Z}_{2}+\delta_{3} \mathrm{Z}_{3}+\delta_{4} \mathrm{Z}_{4}+\delta_{4} \mathrm{Z}_{4}$ $+\mathrm{Wi}$

Where :

$\mathrm{Ui}=$ Technically inefficiency value

$\delta_{0}=$ Konstanta

$\mathrm{Z}_{1}=$ Farmers age

$\mathrm{Z}_{2}=$ Farming Experience

$Z_{3}=$ The number of family members

$\mathrm{Z}_{4}=$ Level of Education

$\mathrm{Wi}=$ Random error term which is assumed to be free and truncated normal distribution $\mathrm{N}(0, \sigma 2)$.

The estimation of the production function and the function of inefficiency carried out simultaneously with the program 
FRONTIER 4.1. This program processing results will give an approximate value of variance in the form of parameterization: $\sigma^{2}=\sigma v^{2}+\sigma u^{2}$ $\gamma=\sigma u 2 / \sigma^{2}$

Where $\sigma^{2}$ is the total variance of the error term, $\gamma$ is called gamma. The parameters of this variance can find the value of $\gamma$, hence $0 \leq \gamma \leq 1$. The value of the parameter $\gamma$ is the contribution of technical efficiency in the overall effect. A value $\gamma$ which closer to 0 implies that many variations of the output observed from the output frontier is due to the influence of stochastic random, while the value of $\gamma$ approaching to one declares that the proportion of random variation in output is explained by the influence of inefficiency or differences in technical efficiency (Ogundari, 2008).

\section{RESULTS AND DISCUSSION}

\section{Analysis of Factors that Affecting Production of Seaweed Farming}

The production function is the physical relationship between the variables described $(\mathrm{Y})$ and the variables that explain $(\mathrm{X})$. Analysis of the production function is used to determine the effect of production inputs on the production result (output) directly and the relationship between the described variable (dependent variable) and the variables that explain (independent variable) at the same time to determine

Table 1. The Results of Multiple Linear Regression Analysis of Factors Affecting the Production of Seaweed in Tarakan

\begin{tabular}{lrrr}
\hline Variabel & Koefisien & \multicolumn{1}{c}{ t-hitung } & \multicolumn{1}{c}{ Sig } \\
\hline Ln of Konstanta & $2,508^{* * *}$ & 20,907 & 0,000 \\
Ln of Extensive Land Area & $0,011^{* * *}$ & 0,100 & 0,001 \\
Ln of Seeds & $0,903^{* * *}$ & 8,193 & 0,000 \\
Ln of Labor & $-0,018^{\text {ns }}$ & $-0,832$ & 0,408 \\
Ln of Fuel & $-0,010^{\text {ns }}$ & $-0,672$ & 0,503 \\
Ln of Age & $0,067^{\text {ns }}$ & 0,927 & 0,356 \\
Ln of Experience of Farming & $0,063^{* *}$ & 2,300 & 0,024 \\
Ln of Amount of Family Members & $0,022^{\text {ns }}$ & 0,620 & 0,537 \\
Ln of Educational Level & $0,010^{\text {ns }}$ & 0,347 & 0,729 \\
Dummy of Location & $0,029^{* * *}$ & 3,370 & 0,001 \\
\hline $\mathrm{R}^{2}$ & & & 0,902 \\
Adjusted $\mathrm{R}^{2}$ & & & 0,892 \\
F Hitung & & & 92,175 \\
F sig. & & & $0,000^{* * *}$ \\
\hline Source: Prinary
\end{tabular}

Source : Primary Data Analysis, 2017

Additional Information :

* $\quad=$ Significant on $90 \%(\alpha=0,1 ; \mathrm{F}$ table $=1,70 ; \mathrm{t}$ table $=1,66196)$

$* * \quad=$ Significant on $95 \%(\alpha=0,05 ; \mathrm{F}$ table $=1,99 ; \mathrm{t}$ table $=1,98667)$

$* * *=$ Significant on $99 \%(\alpha=0,01 ; \mathrm{F}$ table $=2,61 ; \mathrm{t}$ table $=2,63157)$

$\mathrm{ns}=$ Not significant 
the relationship between the explanatory variables.

To find and measure the influence of the independent variable on the dependent variable multiple linear regression analysis was performed. Multiple linear regression analysis in this study was conducted to determine the factors that significantly affect the dependent variable that is the production of seaweed.

The values of adjusted $\mathrm{R}^{2}$ which is greater shows that the regression model being better because the proportion of the dependent variable explained by the independent variable increases. The analysis shows adjusted $\mathrm{R}^{2}$ value is 0,892 means that $89,2 \%$ of the variation of dependent variables can be explained while the remaining $10,8 \%$ is explained by other variables outside the model.

The results of the analysis using the $\mathrm{F}$ test shows that the value of $\mathrm{F}_{\text {count }}$ is 92,175 and $\mathrm{F}_{\text {table }}$ is 2,61 with a probability is 0,000 , it means that $\mathrm{F}$ count $>\mathrm{F}$ table at the level of significant $\alpha=1 \%$. This shows that the production of seaweed farming in Tarakan jointly influenced by independent variables. Then, the effect of variation of independent variable on the dependent variable can be performed by t-test.

Not all input variables have a positively affects in seaweed farming production. Extensive land area variable (X1), seeds (X2) and dummy location have a significantly at $\alpha=1 \%$. The variables that significantly at $\alpha=5 \%$ and $\alpha=10$ $\%$ is the experience of farming (X6). Estimated value parameters on seaweed production model is the value of elasticity. The elasticity coefficient or production for wide input extensive land area, number of seeds respectively each are $0,011,0,903$.

The amount of seeds has the greatest elasticity $(0,903)$, it means that if the amount of seed is added 1 percent from the total average 5,05 tons, the production of seaweed produced increased by 0,903 $\%$. This is in line with the results of Azwir et al (2011), where seed variable is the main variable that is most influential in increasing the production of seaweed. Seaweed seeds used by farmers in Tarakan coming from the cultivation of seaweed was 30 days which was cultivated by farmers around Amal Beach.

The variable having the smallest elasticity value is land area variable that is equal to 0,011 , meaning that if the average usage of $8.985 \mathrm{~m}^{2}$ land area increased 1 percent, or about $89,85 \mathrm{~m}^{2}$. The other input is considered permanent. It will increase seaweed production as much as $0,011 \%$ of the average production that can be produce. Land area used by seaweed farmers constructed using several large wood as the basic foundation which is then linked to each other by using a rope. The seeds that have been overlaid on top land area can still floats, farmers should use several bottles or cans of former tied 
a rope around a wooden foundation. Land area foundation should be tied strongly so that it is not easily slammed by the waves that can actually make the seed loss of the strings attached.

Labor and fuel have a negative coefficient respectively each are $-0,018$ and $-0,010$. It means if the average HKO increased 1 percent would decrease seaweed production amounted to $0,018 \%$. This is in line with the results of Otitoju (2012), where the addition of the use of labor will reduce production. The increase of 1 percent from the average use of 260 liters fuel it will decrease seaweed production amounted to $0,010 \%$.

Experience of farming is significant at alpha $5 \%$ and it has coefficient 0,063 , it means that farming experience has a significant influence in increasing seaweed production. The trend is that farmers who have longer experience will produce higher seaweed than farmers who do not have long experience.

The regression coefficient of dummy location is 0,029 and significant at alpha $1 \%$. It means that the location affects the production of seaweed. The tendency is the more secure the location chosen by farmers to cultivate seaweed will increase the production of seaweed approximately $0,029 \%$. When farmers reached more than $10 \mathrm{~km}$ is feared will disrupt ship traffic lane and has impact on the destruction of seaweed plants that have been released into the sea. The underlying reason on why farmers choose to let the seeds of seaweed exceed secure limits set by the government is because farmers perceived that the further the land area is further from the shore, the better results the seaweed obtained. Moreover, the more tightrope released causes more widely spaced to be used by farmers.

Average production of seaweed produced by farmers in 2016 was 28,41 tons at an average use of each variable in a year are $8.985 \mathrm{~m}^{2}$ for land area wide, 4,72 tons of seed, 282,46 liters for fuel average use and labor usage is $1194 \mathrm{HKO}$. On average farmers to grow as much as 5 to 6 times a year with the planting period up to 2 months to harvest.

\section{Technical Efficiency Analysis of Seaweed in Tarakan}

Technical efficiency value can be obtained by estimating the ratio between actual production and potential production that farmers might be achieved through good management. Technically efficient input use to say if the input is used to a certain extent can produce the maximum or minimum production may use the input to produce the maximum output.

Table 2 shows the analysis result of the production model stochastic frontier for seaweed farming in Tarakan. Variables were significant at $\alpha=1$ percent of the 
production boundary (frontier) seaweed is a labor variable (X3). This is in line with the results of research conducted in the Philippines where labor has a major role in the farming of seaweed (Valderrama, 2013). On the other hand, the variables are significant at $\alpha=5$ percent was widely land area (X1) and seeds (X2). All variables will be correlated with each other and will determine the level of efficiency achieved (Kusnadi et al, 2011).

The results of the analysis in Table 2 also illustrates the value of a variant or sigma-squared $\left(\Sigma^{2}\right)$ and parameter of gamma $(\gamma)$ of the technical inefficiency effects model stochastic frontier production function on seaweed farming. The value of $\Sigma^{2}$ shows that the distribution of technical inefficiency error term (Ui), where the value is 0,443 .

The value is small or close to zero so it can be said that it is normally distributed. Meanwhile, the value of $\gamma$ is 0,790 where $\gamma$ is the ratio between deviase technical inefficiency (Ui) of the deviation may be due to random factors (Vi). This number shows that the error term comes largely from inefficiency (Ui) and just a little bit from the noise (Vi) or random error. Meanwhile, if the value of $\gamma$ close to zero, then the error such as weather, climate, pests and diseases, etc which are not the result of inefficiency (Kibaara, 2012). It is also indicated in the value of generalized Likelihood Ratio (LR), where the value is 49,038 . This value is greater than the

Table 2. Analysis Result of Seaweed Farming Use Stochastic Frontier Production Model in Tarakan on 2016

\begin{tabular}{|c|c|c|c|c|}
\hline Variable & Coefficient & Standard Error & \multicolumn{2}{|c|}{ t-ratio } \\
\hline Constant & 0,579 & 0,302 & & 6,79 \\
\hline Extensive Farm Area $\left(\mathrm{X}_{1}\right)$ & $0,112 * *$ & 0,028 & & 4,02 \\
\hline Seeds $\left(X_{2}\right)$ & $0,489^{* *}$ & 0,042 & & 3,89 \\
\hline Labor $\left(\mathrm{X}_{3}\right)$ & $0,222 *$ & 0,073 & & 1,72 \\
\hline Fuel $\left(\mathrm{X}_{4}\right)^{3}$ & $-0,551$ & 0,569 & & $-4,61$ \\
\hline Sigma-squared $\left(\Sigma^{2}\right)$ & 0,443 & 0,652 & & 1,86 \\
\hline $\operatorname{Gamma}(\gamma)$ & 0,790 & 0,189 & & 21,84 \\
\hline Log-likehood function OLS & & & & 0,499 \\
\hline Log-likehood function MLE & & & & 0,328 \\
\hline LR Test of the one $=$ sided error & & & & 49,038 \\
\hline Age $\left(Z_{1}\right)$ & $0,192 *$ & & 0,815 & $-1,32$ \\
\hline Experience of Farming $\left(\mathrm{Z}_{2}\right)$ & $-0,224 *$ & & 0,081 & 1,14 \\
\hline Family Members $\left(Z_{3}\right)$ & $0,288^{*}$ & & 0,130 & 2,78 \\
\hline Educational Level $\left(Z_{4}\right)$ & $0,134 *$ & & 0,446 & 2,10 \\
\hline Dummy of Location & $-0,458^{*}$ & & 0,446 & $-4,08$ \\
\hline
\end{tabular}

Source : Primary Data Analysis, 2017

Additional Information :

$* \quad=$ Significant on $90 \%$

** $\quad=$ Significant on $95 \%$

$* * * \quad=$ Significant on $99 \%$ 
value of Kodde and Palm table on the level of $\alpha$ is 5 percent $(8,761)$, means that the amount of seaweed production in Tarakan influenced by farmers' technical efficiency and inefficiency.

Technical inefficiency on seaweed farming in Tarakan is influenced by internal factors or other factors beside farmers' production inputs. Factors or variables suspected to affect the technical inefficiency on the farm are age of farmers (Z1), the experience of farming (Z2), the amount of family members (Z3), educational level (Z4), and the dummy location (Z5). Output function resulting inefficiency is the result of simultaneous processed with the production function. This is due to the inefficiency of the error terms of production functions are generated. The results of inefficiency function can be seen in Table 2, where the coefficients of each variable are positive and negative. Variables that has a positive coefficient are age, amount of family members and educational level. That is, that the older the seaweed farmers, the big number of family members covered and the higher the level of education a seaweed farmer, it will increase the level of inefficiency or in other words it will reduce the level of technical efficiency of seaweed farming.

The age variable included in the model determines the effect of age on farm efficiency. Assumptions built is that the higher the age, the more inefficient farmers in carrying out their farming. Age is expected to be positively correlated to inefficiency. The results showed that the age allegations do not affect the inefficiencies albeit with a positive sign that the age variable is a variable that is not important in influencing the efficiency achieved by farmers in carrying out their farming. This means that farmers who were young or old farmer has a same chance to achieve maximum results in the farming of seaweed. This is in line with the results of Hormodzi (2012) found that age correlated positively and does not affect inefficiency.

Family members is a source of labor to substitute non-family labor. More and more members of the family, the more that participate in the farming thus reducing technical inefficiency. The results showed that the number of family members has a positive coefficient value which means that family members of farmers are a variable that are not important in influencing the efficiency achieved by farmers. Farmers who have many family members or not has an equal chance to achieve technical efficiency.

The level of educational is the education of farmers ever spent on formal education. The level of education of farmers will affect the decision-making in farming. The level of education is positive and does not significantly affect the inefficiencies that this variable is not important in influencing the efficiency achieved by farmers. This indicates that 
efficient or not the seaweed farming is not due to the influence level of education that is owned by farmers. Facts on the ground indicate that the majority of farmers have a low education level. Farmers who have primary school educational background are equal to $32 \%$. Farmers with junior high school educational background are $45 \%$, $19 \%$ high school educated and educated Bachelor of $1 \%$ and the others are not graduated. The education of farmers do not really affect the production of seaweed in Tarakan because basically farming seaweed is not too difficult to do, even though this led to contradictory with the results Msuya et al (2008) which states that formal education can reduce technical inefficiency in maize in Tanzania. However, in line with research of Nyagaka et al (2010).

While the variable that has negative coefficients are experience of farming and dummy location. Unlike the case of variables that are positive, the variables that are negative will reduce the level of inefficiency or will increase the level of technical efficiency seaweed farming. Farming experience or proficiency affects the ability of farmers in farming. Experienced farmers generally have a wider network and tend to apply information technology obtained. The longer experience in farming and farmers making rational decisions for farming. The results show that the allegations of farming experience is negative and significant. This suggests that the experience of farmers is an important factor affecting the technical efficiency achieved by farmers. It indicates that the longer farmers have experience in seaweed farming will further improve the technical efficiency of seaweed farming.

Dummy location is also a negative value indicates that the location was influential in improving technical efficiency to be gained by seaweed farmers in Tarakan. The secure location chosen by farmers to grow seaweed would further reduce farmers' technical inefficiency.

The average value of the respondents' technical efficiency in a secure location is 0,93 , which means that the production of seaweed which can be generated at a secure location reaches $93 \%$ if it is operated efficiently. Production could be increased to $7,52 \%(7 / 93 \times 100 \%)$ from realization of production $(14,28$ ton) so that production can be achieved by seaweed farmer respondents in a secure location category amounted to 15,35 ton. On the other hand, the average value of the respondents' technical efficiency at unsecure location category is 0,82 , which means that the production of seaweed which can be generated at unsecure location could be up to $82 \%$ if it operates efficiently. Production could increase to $21,95 \%$ (18/82 x 100\%) from realization of production (13,04 ton) so that production can be achieved seaweed farmer respondents in the category of unsecure location is 15,90 tons. 
Table 3. The Distribution of Technical Efficiency Levels of Seaweed Farmers in Tarakan, 2016

\begin{tabular}{lrrrr}
\hline \multirow{2}{*}{ Efficiency Levels (\%) } & \multicolumn{2}{c}{ Secure Location } & \multicolumn{2}{c}{ Unsecure Location } \\
\cline { 2 - 5 } & Total Farmers & Percentage & Total Farmers & Percentage \\
\hline$\leq 50$ & 0 & 0 & 0 & 0 \\
$51-60$ & 0 & 0 & 2 & 5 \\
$61-70$ & 0 & 0 & 2 & 5 \\
$71-80$ & 1 & 1,7 & 10 & 25 \\
$81-90$ & 9 & 15 & 19 & 47,5 \\
$91-100$ & 50 & 83,3 & 7 & 17,5 \\
\hline Total & 60 & 100 & 40 & 100 \\
\hline Maximum & & 0,98 & & 0,93 \\
Minimum & & 0,77 & & 0,54 \\
Average & & 0,93 & & 0,82 \\
\hline Source
\end{tabular}

Source : Primary Data Analysis, 2017

As many as 60 respondents or 100 percent of farmers who are in a secure location category achieve efficiency levels above $0,70 \%$. The number of farmers who are in the category of unsecure locations are 40 people and of that number who have an efficiency level above $0,70 \%$ are 31 farmers, or about $90 \%$. Farmers in secure locations achieve an average efficiency and want to achieve maximum efficiency of the opportunities to increase production amounted to $7,14 \%((1-0,93) / 0,98)$. The same calculation if farmers having a minimum efficiency values want to achieve maximum efficiency, the opportunity to increase production is by $23,47 \%$ ((1-0,77) $/ 0,98)$. Similarly, farmers under unsecure location, a farmer achieve average efficiency and want to achieve maximum efficiency of the opportunities to increase production amounted to $19,35 \%((1-0,82) / 0,93))$ and the chances of farmers who have minimum efficiency values for increased production is amounted to $49,46 \%((1-0,54) / 0,93)$.
The average value of the technical efficiency of seaweed farmers in general is 0,92 . This figure means that the production of seaweed in Tarakan only reached $92 \%$ of the production potential that can be produced if operated efficiently. Based on the average value of technical efficiency, then the seaweed farming in Tarakan already said to be efficient. According Coelli (1998), the efficient frontier is when farmers have reached the level of efficiency 0,7 or $70 \%$. If any seaweed farmer respondents were able to operate efficiently, then the Tarakan seaweed production in 2016 could rise to $8,7 \%(8 / 92 \times 100 \%)$ of the total optimal production that can produced (27,6 tons). If any seaweed farmers are able to operate efficiently, Tarakan seaweed production in 2016 potentially can achieve up to 30 tons of dried seaweed. Based on the results of parameter estimation on the production function inputs, some real positive effects on the seaweed production are land area, 
number of seeds, labor and location. It means that if all inputs are used, it will increase seaweed production. Production input that has the greatest elasticity value is seed.

\section{CONCLUSION AND SUGGESTION}

\section{Conclusion}

Based on the analysis using the OLS method showed that the factors of production which have positive effects on the production of seaweed in Tarakan are land area widely, seeds, experience of farming, distinguishing seaweed production in secured and unsecured locations. Based on Stochastic Frontier analysis results obtained, $\gamma$ value is 0,790 . Average technical efficiency seaweed farmers obtained was 0,92 which later can be categorized as efficient, even though farmers still have the chance to improve the efficiency until 0,8 . The value of the average technical efficiency for secure and unsecure locations are 0,93 and 0,82 respectively.

Socio-economic factors affecting technical inefficiency are age, number of family members and education level. However, just the experience of farming and the dummy location having a negative coefficient value, which means that the longer farmers have experience in seaweed farming and more secure location chosen to cultivate seaweed, the lower the level of technical inefficiency will be.

\section{Suggestion}

Seaweed farmers need to receive the socialization and training related to the secure distance for locations that will be used to cultivate seaweed because the location of Tarakan are often traversed by sea transport from the surrounding area. Farmers need to increase the outpouring of labor especially for maintenance activities that damage seaweed production can be minimized. In addition, the provision of production inputs from government assistance which does not match to what farmers need could not be used properly.

\section{REFERENCES}

Ajao A.O, Ogunniyi LT, Adepoju AA. 2012. Economic Efficiency of Soybean Production in Ogo-Oluwa Local Government Area of Oyo State, Nigeria. American Journal Experiment Agr. 2(4) : 667-679.

Azwir, Jangkung, dan Any. 2011. Analisis Finansial dan Efisiensi Produksi Usahatani Rumput Laut di Kota Kendari. Jurnal Agro Ekonomi Vol. 18 No.1.

Badan Penelitian dan Pengembangan Kelautan dan Perikanan KKP Republik Indonesia. 2010. Budi Daya Rumput Laut Penghasil Karaginan (Karaginofit). Jakarta.

Coelli, T.J., 1995. Recent Developments in Frontier Modelling and Efficiency Measurement. Australian Journal Agro Economy. 39(3): 219-245.

Dinas Kelautan dan Perikanan Tarakan. 2015. Produksi Rumput Laut Kering dan Basah Kota Tarakan. 
Food and Agricultural Organization of The United Nations. 2013. http://fishstat. fao.org/fishstat/

Hormozi M.A, Asoodar MA, Abdeshahi A. 2012. Impact of Mechanization on Technical Efficiency: A Case Study of Rice Farmers in Iran. Proc Econ Finan. 1 : 176-185.

Kibaara B.W., dan Kavoi M.M. 2012. Application of Stochastic Frontier Appoach to Assess Technical Efficiency in Kenya's Maize Production. JAGST. 14(1) : 3- 20.

Kusnadi et al. 2011. Analisis Efisiensi Usahatani Padi Di Beberapa Sentra Produksi Padi Indonesia. Jurnal Agro Ekonomi 29(1) : 25-48.

Msuya, E.E., S. Hisano, and T. Nariu. 2008. Explaining Productivity Variation Among Smallholder Maize Farmers in Tanzania. MPRA Paper Number 14626. Online at http://mpra.ub.unimuenchen.de/14626.

Nyagaka,D.o., A. Gideon, Obare, J.M. Omiti, and W. Nguyo. 2010. Technical Efficiency in Resource Use: Evidence From Smallholder Irish Potato Farmers in Nyandarua North District, Kenya. African
Journal of Agricultural Research (AJAR) 5 (11) : 1179-1186.

Ogundari K, Ojo SO. 2007. An Examination of Technical, Economic and Allocative Efficiency of Small Farms : The Case Study of Cassava Farmers in Osun State of Nigeria. Bulgarian Journal of Agricultural Science, National Centre for Agrarian Sciences. 13 : 185-195.

Otitoju M.A, et al. 2012. Technical Efficiency Differentials and Resource-Productivity Analysis among Smallholder Soybean Farmer in Benue State, Nigeria. Journal of Research Agriculture 1 (2) : 108-113.

Valderrama, D., Cai, J., Hishamunda, N. \& Ridler, N., eds. 2013. Social and economic dimensions of carrageenan seaweed farming. Fisheries and Aquaculture Technical Paper No. 580. Rome, FAO. 204 pp.

Viswanathan et al., 2001, "Fishing Skill in Developing Country Fisheries : The Kedah, Malaysia Trawl Fishery," Marine Resource Economics, Vol. 16 (IV). 